\title{
Representasi stereotip perempuan dalam musik dangdut: hegemoni kuasa dan strategi untuk bertahan
}

\author{
Reni Ferlitasari \\ Universitas Indonesia, Depok, Jawa Barat - Indonesia \\ Email : reniferlitas@gmail.com
}

Article Information

\begin{tabular}{llll}
\hline Submitted & $: 2021-05-18$ & Revision & $: 2021-20-30$ \\
Reviewed & $: 2021-09-25$ & Published & $: 2021-11-30$
\end{tabular}

Abstract: This research aims to explain the empowerment and capacity of an actor in dangdut music industry. Specifically, it tries to explain the knowledge, involvement, capacity and empowerment of a female singer acting in carrying songs containing what is considered vulgar values or not. Using the social praxeology concept by Bourdieu, this research argues that female singers are dominating actors in terms of dangdut music industry's growth, though their own positions are not always special, and often enough, at its rock bottom. The stereotype role of a women's sex and objectification both on the paper or visually can impacts her in social culture system, the self-sexualization of a women actor creates an instruct representation in public. This study uses a qualitative method with data collecting that consists of interviews with 5 female singer actors within dangdut orchestran music industry Alta Musik Pugung.

Keywords: Empowerment, Capacity, Female Singer, Dangdut Music, Music Industry

Abstrak: Penelitian ini bertujuan untuk menjelaskan keberdayaan dan kapasitas aktor dalam industri musik dangdut. Lebih spesifik, penelitian ini mencoba untuk menjelaskan pengetahuan, keterlibatan, kapasitas dan keberdayaan penyanyi perempuan yang berperan dalam membawakan atau tidaknya lagu yang mengandung nilai-nilai yang dianggap vulgar. Menggunakan tipologi kualitatif dengan pendekatan studi kasus, penelitian ini berargumen perempuan menjadi aktor yang sangat mendominasi dalam perkembangan industri musik dangdut, namun posisinya tidak selalu menduduki tempat istimewa bahkan tidak sedikit justru merugikan. Stereotip peran seks dan obyektifikasi perempuan baik dalam wacana maupun visual berdampak bagi dirinya dalam tatanan sosial budaya, seksualisasi diri oleh aktor perempuan menciptakan representasi yang kemudian mengkronstruksi di masyarakat. Kajian ini menggunakan metode kualitatif 
dengan pengumpulkan data wawancara mendalam terhadap lima aktor perempuan penyanyi yang bergabung dalam Industri musik dangdut orkestra Alta Musik Pugung.

Kata Kunci: Keberdayaan, Kapasitas, Perempuan Penyanyi Danhdut, Industri Musik

\section{Pendahuluan}

Studi ini adalah studi yang membahas keberadaan aktor perempuan penyanyi dalam industri musik dangdut, bagaimana pengetahuan dan kapasitas penyanyi perempuan sangat mempengaruhi keberdayaannya baik didalam industri musik dangdut itu sendiri (sehingga akan/tidak dalam membawakan lagu, gaya berbusana, gaya manggung/pentas yang mengandung nilai-nilai yang dianggap vulgar) maupun dalam tatanan sosial budaya di masyarakat (keberdayaannya dan orangorang terdekatnya yang dipandang sebelah mata akibat cerminan dirinya di dalam industri musik dangdut).

Kajian representasi perempuan dalam musik dangdut memang tidak sedikit, namun pertimbangan terhadap posisi aktor dalam industri musik dangdut masih langka. Beberapa penelitian telah melakukan analisis mendalam dan eksplorasi terhadap perempuan dalam musik dangdut namun terbatas pada wacana dan visual dimana lirik dan video klip menjadi perhatiannya tanpa memperhatikan posisi aktor didalam industri musik dangdut. Kusumah (2016) berfokus pada kajian wacana terhadap lirik dengan menggunakan teori semiotika sementara Natali (2016) melihat kenikmatan visual terhadap tubuh perempuan dalam musik dangdut di Indonesia menggunakan Analisa resepsi terhadap penonton demo klip duo srigala kemudian, Laili (2015), Willoughby (2015), Natali (2016), Kusumah (2016), Herawati, Ida (2018) dan Weintraub (2018). Objektifikasi tubuh perempuan, stereotip peran seks, seksualisasi diri adalah beberapa stereotip hasil temuan studistudi terdahulu terhadap perempuan dalam musik dangdut namun, mereka terbatas dari wacana dan visual terkait lirik dan video klip. Studi yang memperhatikan posisi aktor perempuan didalam industri musik dangdut hampir tidak ada. Studi ini mirip dengan penelitian Chaniago, Rizki Hafiz \& Hasan, Fauziah Kartini (2016), Saara Liinamaa \& Malia Rogers (2020) dan Andrea Decker (2020) dimana mereka samasama memperhatikan posisi aktor perempuan didalam layar kaca industri, namun berbeda dalam konteks dan kerangka teorinya yang bukan dalam industri musik dangdut. Hal ini merupakan pra-bukti bahwa perhatian terhadap posisi aktor didalam industri msik dangdut bagaimana pengetahuan, kapasitas, strategi dan 
keberdayaan mereka sebagai penentu kualitas perempuan dalam industri musik dangdut dengan menggunakan konsep habitus Pierre Fellix Bourdieu dengan pendekatan praxiology social hampir tidak ada.

Industri budaya merepresentasikan bagaimana seksisme kontemporer semakin dinamis, seluler, dan gesit (Gill R, 2014) dan ketidaksetaraan gender lebih sulit untuk menyuarakan karena citra industri adalah kreatif dan progresif. Dalam pemikiran Bourdieu kondisi sosial berperan dalam mengkonstruksi persepsi-persepsi individual, bahkan berperan dalam menstruktur pengalaman/tindakan komunikasi personal (Lubis, 2016) sehingga sangat mempengaruhi posisi aktor untuk bertindak yang dalam hal ini adalah perempuan penyanyi dangdut bagaimana mereka dalam bernegosiasi untuk mempertahankan kualitasnya sehingga akan/tidak dalam membawakan lagu, gaya berbusana, gaya manggung/pentas yang mengandung nilai-nilai yang dianggap vulgar.

Kerangka konsep habitus Bourdieu digunakan sebagai kerangka teori dalam penelitian ini untuk menjelaskan bagaimana keberdayaan dan kapasitas aktor perempuan penyanyi dangdut dalam memberikan pengaruh terhadap sebuah arena habitus untuk bertahan sekaligus penentu kualitas dirinya dalam industri musik dangdut. Selain itu, penelitian ini juga memberikan gambaran teoritis refleksi keandalan mengenai konsep habitus dengan pendekatan praxeology social Bourdieu melalui wawancara mendalam terhadap lima orang perempuan penyanyi yang bergabung dalam industri musik dangdut orkestra Alta Musik Pugung.

Berdasarkan penjelasan yang sudah dipaparkan maka penelitian ini secara khusus dirancang untuk menjawab dua pertanyaan utama. Pertama, bagaimana keberdayaan aktor perempuan penyanyi dangdut dalam habitus Industri musik dangdut. Kedua, bagaimana kapasitas dan strategi yang dilakukan perempaun penyanyi dangdut untuk bertahan dalam industri musik dangdut?. Secara umum penelitian ini bertujuan untuk menemukan representasi perempuan dalam musik dangdut bukan terbatas wacana dan visual tetapi lebih kepada keberdayaan dan kapasitas nya yang dipertaruhkan dalam menghadapi hegemoni industri yang kreatif dan progresif yang terus menstruktur. Dengan menggunakan tipologi kualitatif dan pendekatan studi kasus diharapkan tulisan ini dapat bermanfaat bagi perempuan penyanyi khususnya dalam industri musik dangdut serta memberikan kontribusi dalam perkembangan studi-studi feminism 


\section{PEMBAHASAN}

\section{Perempuan Dalam Musik Dangdut}

Musik dangdut memang menjadi isu yang sangat menarik untuk dikaji ketika dikaitkan dengan wanita. Studi Feminism diseluruh dunia mengakui bahwa pekembangan musik dangdut di Indonesia dengan perbagai macam variannya dewasa ini cukup membanggakan sekaligus membimbangkan. Dangdut menjadi salah satu sarana komoditi bisnis dunia permusikan di Indonesia dan menjadi genre musik terpopuler kedua setelah pop. Hal ini menjadi peluang bagi sebagian pembisnis media untuk menjadikan musik dangdut sebagai komiditi bisnis tak terkecuali dangdut orkestra. Perempuan menjadi aktor yang mendominasi perkembangan musik dangdut hingga saat ini dengan memanfaatkan tubuh perempuan untuk menarik penikmat dangdut menjadi lebih banyak. Liostin menjelaskan bahwa hal ini menimbulkan kuasa patriarki atas seksualitas pada musik dangdut semakin menguat dan perempuan hanya berada dalam wilayah domestik saja (Lahdji, Rima Firdaus, 2015).

Tubuh perempuan menjadi topik pembicaraan dan kajian yang menarik perhatian dalam musik dangdut. Kontroversi terhadap kemunculan penyanyi dangdut perempuan di Indonesia yang kemudian melahirkan pandangan yang pro dan kontra dalam masyarakat terkait hasil dari tampilan mulai dari gaya busana, gaya manggung ataupun lagu yang dibawakan begitu juga dengan video klip yang dihasilkan dengan kelunturan tubuh lebih menonjol daripada unsur substansial dari penyanyi dangdut (Chaniago dkk, 2016), ini merupakan hal yang penting dan menarik bagi sebagian ilmuan untuk menjadikan objek dalam penelitian bahkan di Indonesia itu menjadi objek penelitian yang paling diminati ketika mengkaji perempuan dalam musik dangdut.

Stereotip peran seks, objektifikasi tubuh perempuan kemudian seksualisasi diri adalah stereotif atau stigma yang ditemukan oleh beberpaa penelitian sebelumnya terkait bagaimana perempuan digambarkan dalam musik dangdut yang kemudian mereduksi dimasyarakat. Tanpa melihat spesifikasi bagaimana aktor penyanyi perempuan itu mempertaruhkan value keberdayaannya baik dalam habitus industri maupun keberdayaannya dalam tatanan sosial masyarakat. Hal ini menjadi wacana atau diskursus besar yang harus dilihat sebagai persoalan. Natalia menjelaskan bahwa interpretasi tubuh perempuan dalam musik dangdut tergantung siapa yang menilai, karena setiap audience yang mendengar memiliki penilaian tersendiri tergantung 
mindset yang mempengaruhi latar belakang pemikirannya (Dwiniscahyaningtyas, Natalia; Suwito, Kandi Aryani, 2020).

Sebenarnya, vulgar muncul karena budaya yang mempengaruhi. Budaya Indonesia yang tidak terbiasa dengan bahasa senonoh dan busana terbuka yang kemudian mengakibatkan perempaun sebagai aktor penyanyi dangdut yang tersudutkan, jika budaya kita terbiasa dengan sedemikian mungkin apa yang disajikan dalam musik dangdut yang dianggap vulgar itu akan biasa saja tidak jadi perdebatan. Untuk menerangi debat pubilk tentang penampilan wanita dan realitas presentasi diri feminine salah satu penulis dari Australia yaitu Nicholas mengkaji wanita berpenampilan rok pendek, rambut bob, dan kegemarannya merokok, minum minuman keras, menari, dan jazz, seni film, mode dan iklan, serta di jalan-jalan kota dari pantai ke pantai menggunakan teori feminine modernity, Ia menjelaskan bahwa wanita yang demikian justru memainkan peran aktif dan bijaksana dalam merangkul budaya konsumen modern, bahkan ketika menghadapi risiko hukuman sosial, ekonomi, dan budaya yang serius (Nicholas, J. 2015). Jelas posisi aktor perempuan penyanyi dangdut kemudian stigma yang mereduksi dimasayrakat adalah permasalah budaya yang sudah melekat di masyarakat.

\section{Perempuan dalam Layar Kaca Industri Musik Dangdut}

Rasionalitas yang terbelenggu oleh hegemoni yang terjadi pada perempuan penyanyi dangdut melalui hubungannya dengan pemilik kendali. Penelitian sebelumnya menjelaskan bahwa pemegang kendala penuh atas apa yang ditampilkan aktor perempuan adalah mereka (industri) dan penonton hanya bisa bersikap pasif menyaksikan pertunjukkannya (Judhita, 2015). Dalam panggung pertunjukkan dangdut, yang termasuk dalam kelas dominan yaitu Pemilik orkes atau pebisnis dan penonton dangdut, sementara biduanita berada dalam kelas subordinat (Puji Sri Endra Kusumawati, Tri Marhaeni Pudji Astuti \& Sucihatiningsih Dian WP, 2017). Bahkan ada hasil penelitian dengan menggunakan analisa persepktif semiotik dengan melihat kedudukan laki-laki dalam sebuah lagu dangdut menjelaskan bahwa posisi perempuan hanya dalam wilayah domestik saja dan laki-laki adalah pemegang superior adalah wajar (Herawati, Ida 2018). Stigma atau stereotif yang dihasilkan itu tidak hanya peran aktif dari aktor atas hasil produksi yang ditampilkan dalam wacana lirik dan video klip melainkan ada hal lain yang berperan aktif dibelakangnya. Judhita (2015) menjelaskan bahwa pemegang kendali penuh atas 
apa yang ditampilkan aktor perempuan adalah mereka dan penonton hanya bisa bersikap pasif menyaksikan pertunjukkannya.

Di satu sisi, struktur-struktur objektif membentuk dasar bagi refresentasirefresentasi dan mengkontruksi paksaan-paksaan structural yang diacukan pada interaksi-interaksi: akan tetapi disisi lain interaksi-interaksi itu juga harus dipertimbangkan, khususnya jika seseorang ingin menjelaskan perjuangan sehari-hari, individu dan kolekti, yang bertujuan mengubah atau melestarikan struktur-struktur yang ada" (Bourdieu, 1989)

Keberadaan perempuan dalam suatu habitus industri memang sulit untuk menyuarakan ketidaksetaraan gender karena citra industri adalah kreatif dan progresif (Saara Liinamaa \& Malia Rogers, 2020). Paksaan-paksaan structural yang mengakibatkan perempuan mengalami tekanan antara negosiasi dan kuasa sebagai penentu kualitas dirinya dalam pekerjaan. Untuk pertahanan mereka dalam industri aktor perempuan harus memainkan stategi ketangguhan, keheningan, humor, penolakan dan penolakan kreatif (Saara Liinamaa \& Malia Rogers, 2020) mengingat hegemoni industri yang kreatif dan profresif yang terus menstruktur. Dalam melihat keberadaan aktor perempuan didalam industri musik dangdut strategi ini dirasa sangat relefan untuk pertahanan kualitasnya sebagai penentu sehingga akan/tidak dalam membawakan lagu yang mengandung nilai-nilai yang dianggap vulgar.

Seperti yang dikatakan oleh Bourdieu bahwa aktor ataupun individu itu memiliki kemampuan bekerja pada tahap internalisasi eksternalitas dimana hal-hal yang bersifat eksternal dan objektif diinternalisasikan memalui arena, juga mampu bekerja pada tahap eksternalisasi internalitas dimana hal-hal yang bersifat subjektif diinternalisasikan (berkaitan dengan habitusnya) artinya agen bukan hanya individu yang bersifat pasif yang patuh dan mengafirmasi struktur objektifnya melainkan juga mampu melakukan agensi dengan struktur subjektifnya sehingga seseorang aktor mampu mempengaruhi struktur objektifnya (Karnanta, 2013). Artinya aktor perempuan penyanyi pun bisa melakukan pertahanan dengan berbagai macam stategi untuk keberdayaan dirinya baik itu dalam industri musik dangdut maupun keberdayaannya dalam tatanan sosial budaya di masyarakat karena hal ini juga pengaruh ataupun cerminan dirinya dalam industri musik dangdut.

\section{Perempuan penyanyi dangdut dalam Habitus Industri Alta Musik Pugung}

Konsep habitus Bourdieu adalah upayanya mensintesiskan dualisme antara aktor/agen/subjektivisme versus objektivise/struktur/aturan/modal. Bourdieu 
menggunakan konsep habitus untuk mengatasi kekeliruan yang mempertentangkan antara "objektivisme" versus "subjektivisme" atau dualisme antara "individu" (agens, aktor) versus "masyarakat" (struktur, institusi, aturan). Bourdieu melihat adanya hubungan dialektis antara unsur subjektif dan objektif, antara unsur yang datang dari luar dengan yang ada di dalam, antara habitus yang menguasai dengan yang dikuasai (Lubis, 2016). Dalam habitus industri musik dangdut Alta Musik Pugung juga demikian, dalam wawancara yang peneliti lakukan salah satu pemilik kendali mengatakan bahwa "kita ada sampai hari ini dan dikenal masyarakat juga tidak terlepas dari peran mereka (penyanyi perempuan) karena tanpa mereka kita tidak dapat bergerak, gak jadi grup seperti sekarang keknya mba" (Mastur, 2020).

Lubis menjelaskan bahwa dalam habitus Bourdieu kita dikenalkan dengan "feel for the game" yaitu tindakan yang diarahkan oleh "rasa permainan" atau norma dan nilai-nilai yang terinternalisasikan oleh individu itu akan dianggap sebagai tindakan rasional oleh orang lain atau pengamat yang tidak terlibat. Seperti permainan yang dilakukan oleh aktor penyanyi perempuan dalam habitus industri musik dangdut Alta Musik Pugung, mereka melakukan tindakan sesuai dengan apa yang sudah terstruktru dalam aksi panggung dan tindakan itu dianggap rasional namun, habitus juga merupakan ruang sosial sehingga dapat mencerminkan posisi seseorang dalam tatanan sosial ekonomi, walaupun tidak secara mutlak dan itu yang tidak sedikit merugikan penyanyi perempuan.

Sama dengan sifat industri pada umumnya, habitus idustri musik dangdut Alta Musik Pugung juga kreatif, progresif dan terstruktur dengan tujuan output yang sangat menguntungkan baik secara finansial maupun citra, sehingga mereka menerapkan sistem bekerja sesuai dengan apa yang menguntungkan di pasaran (selera masyarakat). Habitus merupakan struktur mental atau kognitif yang diinternalkan (internalized) yang melaluinya individu memahami kehidupan sosial (Lubis, 2020). Para aktor penyanyi dangdut yang tergabung juga memahami apa yang disukai dan menarik bari masyarakat (penonton) dan menguntungkan bagi habitus (industri) sehingga mereka juga mengetahui apa yang harus dilakukan dalam rangkaian seluruh tampilan panggung (termasuk tata busana dan tarian) walaupun ada sebagian diluar kehendak mereka (pepanyi perempuan). Hal ini selaras bahwa habitus itu structured structure yaitu dihasilkan (dikonstruksi) serta structuring structured yaitu menghasilkan (mengkonstruksi) masyarakat yang mempengaruhi dan menetukan nilai selera individu karena habitus menjadi mediasi antara struktur 
dan praktik, dimana habitus berkaitan erat dengan modal, khusunya modal simbolik pada diri seseorang (Lubis, 2016).

Saya laki-laki jelas saya suka saya gak munafik mba... Saya fokus gimana caranya masyarakat dan penonton suka, kita tampung apa yang masyarakat (penonton) suka dan itu yang saya dan team terapkan sama biduannya.. gak ada kesulitan sejauh ini soalnya mereka juga mau menjalankan apa yang sudah disepakati kan pasti ada yang nyawer ya duit saweran itu punya mereka.... Saya selalu ngasih tau kapan jadwal manggungnya dan masalah tamilan panggung mereka udah ngerti tentunya yang menarik yang disukai masyarakat (penonton) (Mastur (salah satu pemilik kendali), 2020).

Terlihat bahwa habitus adalah "structuring structure" atau "struktur yang menata" termasuk struktur luar dengan menghasilkan strategi-strategi tindakan pada aktor-aktor lain yang pasti memengaruhi faktor eksternal (Swartz, 1997) peran aspek struktur yang kuat pada habitus, menurut Bourdieu tidak selalu dan sepenuhnya menentukan aksi/tindakan individu karena masih dimungkinkan adanya improvisasi. Menurut Bourdieu habitus bukan sesuatu yang mapan, stabil, akan tetapi ada evolusi konstan dan kemungkinan praktik yang berbeda tergantung pada lingkungan eksternal (field) tempat Ia tertanam.

Ya kita kan orkes ya genre musik dangdut yang paling menarik itu ya remix, yang rame, yang seru ya sudah pasti kita sesuaikan penyanyi nya harus gimana.. kita itu manggung rata-rata 7-8 jam dengan penyanyi 3-4 orang.. dan gak harus pakaian terbuka, kalo untuk hal itu ada sebagian yang itu udah kemauan Dia.. ya selama durasi itu kan gak selalu remix dengan lagu dan goyangan yang seperti itu. Pasti ada dan saya pastikan ada juga dari artis kita yang biasa ajaa pakaiannya gak seski, suaranya dia bagus masyarakat (penonton) suka ya tetep kita pake... Sejujurnya yang menarik pasti ya yang cantik, kulit putih, badannya bagus, suara oke.. Cuma ya gak banyak yang seideal itu (Mastur, 2020)

Sifat habitus yang memproduksi menjadi dasar bagi penjelasan bahwa agen tidak bersifat pasif, tetapi agen bersifat aktif. Dengan demikian ciri habitus tidak pasti, generative, dan samar-samar mencerminkan sifatnya yang tergantung. Habitus bukanlah gaya budaya yang menyatu dari seseorang atau sekelompok yang berperilaku seragam pada semua situasi melainkan diperoleh dan dijalankan secara unik dalam hubungan dengan wilayah-wilayah, domain, lapangan (field) yang berbeda (Bourdieu, 1993). Habitus adalah sebuah sistem yang bertahan lama, disposisi yang mudah dipindahkan dan menjadi mediasi antara struktur dan praktik. 
Kita juga menyesuaikan gak semua artis kita samakan, karena memang ada yang Dia menolak aturan kita, Dia gak suka pakaian seksi ya kita gak masalah selama dia menarik dan disukai masyarakat (penonton) misalnya karena wajahnya cantik atau karena suaranya bagus (Edo, PJ daerah Kab. Tanggamus 2020).

Bourdieu mengemukakan bahwa habitus tidak berarti korban sepenuhnya dari lingkungan sosial (struktur), karena aktor memiliki sejumlah strategi dalam proses pembentukannya, bertindak secara reflektif dan hati-hati, walaupun tindakan dan refleksinya termasuk ruang kemungkinan terstruktur yang mendefinisikan style hidup aktor/agen (Bourdieu, 1984). Sehingga, tak sedikit aktor penyanyi perempuan dinilai berdasarkan apa yang Ia tampilkan dalam industri (saat manggung) oleh masyarakat.

Habitus berperan dalam mempertahankan hierarki dan menganggap sesuatu sebagai hal yang alami, absah, dan tidak terhindarkan. Habitus berperan menentukan apa yang terbayangkan dan tidak terbayangkan bagi agen sosial (aktor penyanyi dangdut maupun masyarakat (penonton). Habitus berperan dalam menentukan apa yang mungkin dan tidak mungkin dalam kehidupan sosial seharihari. Dari pandangan ini dapat dikatakan bahwa habitus adalah mekanisme sentral untuk memproduksi struktur politik, sosial dan ekonomi dalam masyarakat (Lubis, 2016) bahkan memproduksi pemikiran yang mereduksi pada masyarakat mengenai perempuan penyanyi dangdut oleh habitus industri musik dangdut.

\section{Keberdayaan Aktor Perempuan Penyanyi dalam Industri Alta Musik Pugung}

Menurut geene, kapasitas adalah kemampuan individu ataupun kelompok untuk melakukan fungsi secara efektif, efisien dan continuity (geenne, 2003). Sedangkan menurut morgan, kapasitas adalah kemampuan untuk melakukan sesuatu, tumbuh, membangun hubungan, memperbaharui diri, menjadi lebih kompleks, kemampuan untuk bertahan hidup yang dilakukan oleh individu maupun kelompok secara efektif dan continuity (morgan. 2006).

Seperti yang dijelaskah oleh Bourdieu bahwa individu ataupun aktor memiliki sejumlah strategi dalam proses pembentukannya (habitus), bertindak secara reflektif dan hati-hati, walaupun tindakan dan refleksinya termasuk ruang kemungkinan terstruktur yang mendefinisikan style hidup aktor/agen (Bourdieu, 1984). Menurutnya sekuat apapun struktur yang terbentuk pada habitus tidak 
selalu dan sepenuhnya menentukan tindakan aktor/individu karena dimungkinkan adanya improvisasi (Lubis, 2006). Aktor memiliki kapasitas ataupun kemampuan untuk bertindak dan melakukan suatu hal sesuai dengan keinginannya.

Aktor penyanyi dangdut dalam industri musik dangdut Alta Musik Pugung pun memiliki kapasitas sebagai individu dalam menentukan apa yang hendak dilakukan. Kapasitas disini adalah kemampuan mereka dalam mempertahankan posisi dirinya dalam industri musik dangdut dimana kreatif, progresif dan terstruktur adalah sifat daripada industri termasuk industri musik dangdut dan mempertahankan posisi dirinya dalam tatanan sosial budaya dimana representasi penyanyi musik dangdut sudah melekat di Sebagian masyarakat. Stereotip peran seks dan objektifikasi perempuan baik dalam wacana maupun visual berdampak bagi dirinya dalam tatanan sosial budaya. Menurut Smolak seksualisasi diri oleh aktor perempuan menciptakan representasi yang kemudian mengkonstruksi di masyarakat (Smolak, Murnen, Myers, 2014).

Sifat industri yang demikian tak jarang memaksa para aktor untuk berperilaku dan berpenampilan diluar kehendak mereka termasuk para penyanyi yang bergabung dalam industri musik dangdut Alta Musik Pugung. Tampilan diatas panggung mulai dari tata busana, lagu-lagu yang akan dibawakan hingga gaya manggung termasuk goyangan juga ada yang ditentukan oleh pemilik kendali dan disampaikan saat briefing sebelum pentas hendak dilakukan.

Keseharianku pake jilbab mba, baru juga sih mba aku pake dulu-dulu emang gak pake cuma ya tetep gak seksi juga... Misalnya kita mau ada jadwal manggung gitu yaa biasanya sebulan sebelum itu udah dikasih tau, oya nanti kita hari ini tanggal ini dapet job disini gitu, kalo untuk make up, baju terusannya dipanggung itu harus joget bikin asik lah gitu itu udah tau mbaa dari awal saya ikutan sini udah dikasih tau sama senior-seniornya ya biar orang suka/seru kan banyak penonton jadi kalo ada lagi yang mau hajatan pasti make kita.. kita yang biduannya juga ikutan dipake. (Tina, 2020)

Dampak dari itu tidak hanya untuk dirinya dalam tatanan sosial budaya tetapi juga bagi orang-orang disekitarnya yaitu anak dan orangtua (bagi penyanyi single). Ada Sebagian dari aktor penyanyi dangdut juga mengetahui akan hal tersebut dan ada juga yang tetap melakukan karena kebutuhan ekonomi.

Saya tau mba sering juga malah tetangga sendiri cuma gak saya gubris, ya sedih mba apalagi kalo anak saya yang kena. Saya punya anak perempuan mba waktu itu dia umur 14 tahun (kelas 2 SMP) kalo sekolah kan pake jilbab anak saya itu kalem banget mba, Waktu itu saya pulang malem sampe dirumah dan anak 
saya belum tidur, dia nyamperin saya bilang gini "mak, kapan sih mau berenti nyanyi, aku dibilang sok-sokan pake jilbab anaknya biduan, mamaknya kan biduan banyak yang nyawer" (Vera, 2020).

Dibuli, pernah juga mba anakku bilang gamau satu kelompok sama dia karena anaknya biduan, sampe nangis... Pengen berenti mba tapi gimana ya kebutuhan anak-anak sekolah, makan dll. Usaha butuh modal suamiku tukang ojek mba (Dewi, 2020).

Dalam mempertahankan kedua posisinya tersebut baik dalam industri musik dangdut maupun dalam tatanan sosial budaya sangat membutuhkan kapasitasnya sebagai aktor untuk keberdayaan dirinya. Kapasitas ataupun kemampun untuk memperbaharui diri dan membangun, kapasitas untuk menolak dan menentang (seperti menolak gaya busana, gaya manggung untuk menarik saweran yang dianjurkan) bahkan kapasitas mempengaruhi (dia mampu meyakinkan para pemilik kendali bahwa Ia mampu mempertahankan banyak job/sewaan group dengan tampil maksimal dan menarik walaupun melepas semua tampilan panggung seperti apa yang dianjurkan saat briefing) yang dilakukan oleh aktor penyanyi dangdut didalam organisasi industri musik dangdut. Sehingga, mengakibatkan keberdayaan posisi terhadap dirinya tidak hanya dalam industri musik dangdut tetapi juga dalam tatanan sosial budaya di masyarakat.

agen yang sukses dari perusahaan multinasional, negarawan, politikus, sampai pada petani sawah di Afrika Utara, misalnya, menurut Bourdieu bukan saja menginternalkan norma-norma permainan, akan tetapi juga memanipulasi aturan atau norma-norma itu (Bourdieu, 1990b). (Lubis, 2016: 124).

\section{Strategi Bertahan Aktor Penyanyi dalam Habitus Industri Alta Musik Pugung}

Salah satu peneliti asal University of Guelph, Kanada study sosiologi dan antropologi yaitu Saara Liinamaa \& Malia Rogers yang tertarik terhadap studi yag fokus terhadap aktor dan posisi aktor didalam suatu habitus salah satu penelitian mereka yang fokus terhadap aktor didalam suatu industri yaitu seni teater dan pertunjukan di New York yang berjudul Women actors, insecure work, and everyday sexism in the Canadian screen industry merupakan penelitian mereka yang menarik perhatian penulis dimana mereka meneliti industri layar kaca yang melibatkan perempuan-perempuan tunduk pada estetika sosio budaya dengan maksud untuk mengkontekstualisasikan budaya toleransi dan pembenaran yang tersebar 
luas (Shelley Cobb \& Tanya Horeck, 2018) dengan menghubungkan masalah ini dengan pekerjaan sehari-hari (diluar industry ini) dan ketenagakerjaan di industri layar kaca. Menariknya dalam penelitian ini mereka mencurahkan perhatiannya pada aktor pekerja akting, mereka melihat dari perspektif aktor perempuan di lokasi pinggiran di Kanada yang mampu berhasil bertahan dalam industri hiburan (akting) meskipun tingkat gesekan yang sangat tinggi.

Salah satu narasumber menggambarkan skenario bahwa semakin berkurangnya peluang professional dimana keahlian dan pengalamannya sebagai seorang aktor tidak diakui atau dihargai dengan baik seiring bertambahnya usia. Mereka melakukan wawancara semi-terstruktur yang mendalam dengan mengidentifikasi strategi untuk bertahan dalam industry untuk menyeimbangkan karena menurut salah satu narasumber yang lain mengatakan bahwa menemukan banyak outlet untuk mewujudkan agen kreatif sangat penting untuk menangkal setiap hari seksisme dan bertahan dalam industry (Saara Liinamaa \& Malia Rogers, 2020).

Saara Liinamaa \& Malia Rogers mengidentifikasi strategi yang dapat digunakan aktor untuk bertahan dalam industri yaitu ketangguhan, keheningan, humor, penolakan dan resistensi keatif (Saara Liinamaa \& Malia Rogers, 2020). Beberapa stategi inilah yang juga dilakukan oleh kelima aktor perempuan penyanyi dalam habitus industri Alta Musik Pugung.

\section{Ketangguhan}

Ketangguhan sebagai strategi kunci untuk menavigasi kehendak pemilik kendali dalam habitus industri. Industri menuntut kita menjadi lebih tangguh dan memiliki tanggung jawab secara efektif terhadap individu (aktor yang bergabung). Yang harus dilakukan oleh para aktor adalah seperti yang disampaikan oleh salah satu narasumber dalam penelitian Saara Liinamaa \& Malia Rogers yaitu seorang aktor perempuan harus memiliki energi agresif.

I just had to be tough and mean and smart and big and get in there and say I can do it, I can overcome and make it happen, because if I had actually admitted what was going on and that my sex was going to inhibit how far my career would go, I may have given up. (Sonya, 2020: 9)

Aktor dalam habitus industri Alta Musik Pugung juga harus memiliki energi agresif ini untuk mewujudkan keberdayaannya baik dalam habitus industri maupun dalam tatanan sosial budaya di masyarakat. Pilihan untuk menjadi 
penyanyi perempan dalam habitus industri orkestra adalah jalan dirinya tanpa adanya paksaan walaupun tentu terdapat berbagai macam pertimbangan diluar kebutuhan dirinya seperti keluarga. Sehingga konsekuensi yang akan diterima sudah dibayangkan sedemikian rupa baik untuk dirinya maupun orang-orang yang berada disekitarnya baik anak, suami maupun keluarga terdekat lainnya. Artinya ketangguhan ini sebagai motivasi awal dari dalam diri seorang aktor.

Saya sudah tau kalau akibatnya seperti demikian, saya harus semangat, saya harus percaya hal baik akan kembali kepada yang baik, saya bekerja untuk keperluan keluarga saya... Saya tidak merepotkan orang lain untuk keperluan, seandainya saya berhenti mungkin tetangga, keluarga akan sring saya datangi untuk meminjam uang. (Dewi, 2020)

\section{Keheningan atau Diam}

Dalam praktiknya seringkali diam justru menjadi jurus jitu dalam situasi yang bahkan memalukan. Diam menjadi strategi jika didampingi dengan stategi lain (ketangguhan). Diam bukan berarti menerima tetapi mempertahankan prospek kedepannya karena situasi yang menuntut demikian. Mengatakan atau memperdebatkan masalah dinamika gender untuk mempertaruhkan hubungan atau prospek kerjanya di masa depan seringkali tidak diperlukan. Saara Liinamaa \& Malia Rogers dalam penelitiannya mengungkapkan salah satu pengalaman narasumbernya ketika salah satu agensi habitus (sutradar) membuatnya berada dalam situasi yang memalukan dan merasa terhina yang dapat dilakukan hanya diam.

He made me, like, stand up while he berated the female wardrobe designer, but he did it in front of like the entire crew, and he was standing, just, like, pointing at parts of my body and being like, 'look what her tits look like, that doesn't look good! No one wants to look at that'... It was so disrespectful, like, he was doing it in front of the entire crew and you know, the director is standing there yelling so everyone's gonna stop ... everyone's ... awkwardly trying not to look (Gracie, dalam Saara Liinamaa \& Malia Rogers, 2020: 9)

Dalam habitus industri Alta Musik Pugung hal yang sama juga dilakukan oleh beberapa aktor namun ada yang berhasil dan ada juga yang tidak. Salah satu dari mereka menjelaskan keberhasilan itu tergantung bagaimana performa mereka dalam menarik peminat/penyuka habitus orkestra ini ketika mereka manggung/ pentas. 
Saya sudah pernah coba diem karena pas saya bilang gamau saya gak pernah lagi dipilih akhirnya saya dapet lagi karena menggantikan temen saya yang kebetulan lagi sakit, terus dibilang lagi "gak apa-apa kamu, tapi kamu mau gak kalo bajunya gini" saya cuma diem aja gak bilang iya gak bilang enggak, terus ditinggal pergi. Saya coba lagi untuk begitu akhinya bisa tapi itu yang keberapa kalinya mba, saya ajak becanda, saya tegas bilang gamau begitu saya maunya begini (Dewi, 2020)

\section{Humor}

Humor digunakan baik untuk mengkritik atau mengarahkan situasi. Misalnya, Gracie berbicara tentang membuat lelucon untuk memecah ketegangan ketika sesuatu yang jelas-jelas bersifat seksis atau tidak nyaman terjadi. Pengalihan ini adalah cara untuk menggantikan masalah dan ketidaknyamanan seksisme, dan menjaga kemiripan profesionalisme. Tapi, dalam kasus lain, humor adalah cara untuk meluncurkannya kritik yang tidak dapat dinyatakan, Ih cantik banget gak sih gue, anggun gitu yaa coba lebih panjang ini lengannya pasti lebih cute yaa, haha (Dwi, 2020). Singkatnya, menurut Robbie humor adalah untuk "mengelola secara pribadi" lebih baik keberatan atau keraguan pribadi daripada mempertaruhkan kesempatan masa depan (McRobbie, 2015).

Habitus musik dangdut Alta Musik Pugung, salah satu narasumber juga mengatakan bahwa humor termasuk stategi jitu karena selain pemilik kendali itu cepat menerima apa yang aktor inginkan juga hubungan para aktor perempuan penyanyi dengan pemilik kendali semakin dekat sehingga untuk melakukan hal yang mereka inginkan lebih mudah untuk diterima walaupun tetap dengan pertimbangan lain yang tidak merugikan mereka (habitus industri).

Saya belum pernah mencoba, mungkin karakter saya dan yang lain tidak mendukung... Tetapi saya melihat aktor lain yang melakukan dan bos terima aja... Yaa, aktor itu memang menarik secara fisik dan sering mendapat permintaan mengisi jadwal manggung/pentas Alta. (Dwi, 2020)

\section{Penolakan}

Penolakan merupakan stategi yang paling sulit untuk dilakukan, hanya sedikit dari beberapa aktor yang berada dalam habitus industri mampu melakukan 
stategi ini. Penolakan dapat dilakukan ketika kapasitas yang dimiliki aktor mampu memenangkan posisinya dalam industri. Kapasitas aktor 'elit' dinilai dapat memberikan bayangan keberhasilan/ memenangkan posisinya atas penolakan yang dilakukan. Dalam habitus industri Alta Musik Pugung terdapat beberapa aktor yang dapat dikatakan termasuk golongan kapasitas aktor elit dengan pertimbangan lama bergabung dengan habitus, mendapat banyak permintaan dari job/penonton untuk mengisi acara manggung/pentas, dan atau secara kriteria fisik memenuhi. Saya bilang anak saya..... Saya gak bisa kalo terus-terusan seperti ini, kasian anak saya, cobalah ngertiin sedikit, tenang aja job kita gak akan berkurang kok. (Vera, 2020).

Strategi satu ini memang cukup sulit dibandingkan yang lain karena konsekuensi yang diterima ketika ditolak oleh pihak kendali bisa menjadi langkah terakhir para aktor didalam habitus industri Alta Musik Pugung. Para aktor harus terdahulu menyadari bagaimana konsekuensi dari langkah yang diambil.

Saya tau pasti gak bisa soalnya saya baru, performa saya juga gak begitu bagus seperti dia (aktor lain), baru juga bisa sebenarnya, ada itu dia baru secara fisik memang cantik terus diajak manggung/pentas banyak yang suka, jadi dia bisa menolak kalau tidak sesuai apa yang dia mau. (Putri, 2020)

\section{Resistensi kreatif}

Resistensi kreatif adalah memiliki kendali atas kedua jenis pekerjaan maksudnya aktor harus memiliki kreatifitas mampu memainkan peran lain diluar kebiasaan perannya. Saara Liinamaa \& Malia Rogers dalam penelitiannya mengungkapkan salah satu pengalaman narasumbernya bahwa aktor tidak hanya menunggu panggilan untuk perannya dalam artian Ia dapat mengajukan diri untuk peran yang lain karena perubahan pasti akan terjadi yang tidak hanya waktu tetapi karakter dan juga budaya.

Saya melihat beberapa aktor perempuan penyanyi yang hebat. Meraka tidak perlu berpakaian seksi, secara fisikly biasa saja, waktu dia bergabung dengan habitus industri Alta Musik Pugung juga belum lama dibandingkan dengan yang lain ... chemistry yang berbeda, nilai jual tersendiri. (Edo, 2020)

Kemampuan untuk mengatur dinamika dalam habitus industri sangat penting. Mereka para aktor perempuan penyanyi harus menyadari kalau tidak ingin melaksanakan apa yang dianjurkan pihak pemilik kendali artinya mereka harus mempunyai nilai jual tersendiri ketika tidak ingin menggunakan baju terbuka, 
gaya manggung/pentas serta membawakan lagu yang dianggap terlalu berlebihan (vular). (Dwi, Dewi, Vera, Putri, Tina, 2020)

Singakatnya, mereka menjelaskan bahwa pada dasarnya semua aktor yang bergabung dalam habitus industri hanya menciptakan yang menghasilkan hubungan yang berbeda, jadi aktor harus mampu kreatif menciptakan suatu hal yang menghasilkan hubungan penentu kemenangan posisinya.

\section{Simpulan}

Representasi stereotip perempuan dalam musik dangdut yang sudah melekat di masyarakat bisa terwujud berkesetaraan gender dan keberdayaan posisi aktor perempuan penyanyi dangdut yang tidak hanya dalam habitus industri tetapi juga dalam tatanan sosial budaya di masyarakat. Seperti yang dikatakan oleh Bourdie bahwa individu ataupun aktor memiliki sejumlah strategi dalam proses pembentukannya (habitus) sekuat apapun struktur yang terbentuk pada habitus tidak selalu dan sepenuhnya menentukan tindakan aktor/individu karena dimungkinkan adanya improvisasi. Bourdieu juga menjelaskan aktor ataupun individu itu memiliki kemampuan bekerja pada tahap internalisasi eksternalitas dimana hal-hal yang bersifat eksternal dan objektif diinternalisasikan memalui arena, juga mampu bekerja pada tahap eksternalisasi internalitas dimana hal-hal yang bersifat subjektif diinternalisasikan (berkaitan dengan habitusnya).

Dinamika antara hegemoni kuasa dan keberdayaan aktor perempuan baik dalam habitus industri musik dangdut maupun dalam tatanan sosial budaya di masyarakat memang menjadi sebuah tantangan yang sangat sulit bagi aktor. Tekanan pemilik kendali, persaingan sesama aktor didalam habitus industri untuk mendapatkan hal yang diinginkan seperti penilaian yang baik dari pemilik kendali sehinga pantas/tidak untuk diajak manggung/pentas, kemudian menentukan bagaimana gaya berbusana, gaya manggung/pentas serta lagu yang akan dibawakan karena yang tidak kalah penting adalah para aktor ini mengetahui bahwa apa yang mereka tampilkan itu akan mencerminkan diri mereka dalam tatanan sosial budaya di masyarakat. Sehingga mereka melakukan berbagai macam stategi untuk menyeimbangkan keduanya.

Strategi yang dilakukan para aktor penyanyi perempuan dalam habitus industri musik dangdut berupa ketangguhan, keheningan atau diam, humor, penolakan dan resistensi kreatif. karena untuk melepaskan diri dari habitus itu suatu hal yang 
tidak mungkin disisi lain mereka membutuhkan pekerjaan itu untuk pemenuhan ekonomi.

\section{Daftar pustaka}

Calogero, R.M., Tylka, T.L., Donnelly, L.C., McGetrick, A., Leger, A.M. (2017). Trappings of femininity: A test of the "beauty as currency" hypothesis in shaping college women's gender activism. Body Image 21, pp. 66-70.

Chaniago, Rizki Hafiz \& Hasan, Fauziah Kartini (2016). Citra Wanita Dalam Perkembangan Muzik Dangdut Di Indonesia. Universitas Kebangsaan Malaysia: Malaysia Journal Of Comunication.

Dwiniscahyaningtyas, Natalia (2016). Kenikmatan Visual (Visual Pleasure) Terhadap Tubuh Perempuan Dalam Musik Dangdut Indonesia (Studi Analisi Resepsi Terhadap Khalayak Penonton Demo Klip Duo Serigala). Unair: Fisip, komunikasi.

Decker \& Louise, A (2016). Performing Gender to Dangdut's Drum: Place, Space, and Infrastuktur in Indonesia Popular Music. Univercity of California, UC Riverside.

Decker, A. (2020) Hidden for Their Protection. University of California, Riverside, United State. Bijdragen tot de Taal-, Land- en Volkenkunde 176(1), pp. 37-69.

Dewi Kusumaningsih, Djatmika Djatmika, Riyadi Santosa, H. Subroto (2019). Pedagogical Values in Indonesian Lyrics of Dangdut Songs: Evidences of Language Vulgarism and Gender Exploitation. Journal of Social Studies Education Research, 10(3), 311-331.

Dwiniscahyaningtyas, Natalia; Suwito, Kandi Aryani. (2020).Visual Pleasure in Women's Bodies within Indonesian Dangdut Musical Scene. Talent Development \& Excellence . 2020 Special issue 2s, Vol. 12 Issue 2, p193-198. 6p. 1 Color Photograph.

Elliott, R., Jones, A., Benfield, A., Barlow, M. (1995). Overt sexuality in advertising: A discourse analysis of gender responses. ournal of Consumer Policy 18(2-3), pp. 187-217.

Gill, Rosalind. (2014). Unspeakable Inequalities: Post Feminism, Entrepreneurial Subjectivity, and the Repudiation of Sexism among Cultural Workers. Social Politics 21 (4): 509-528. doi:10.1093/sp/ jxu016. 
Herawati, Ida (2018). Seksisme Dalam Lagu Bojoku Galak Via Valen. Balai Bahasa Kalimantan Barat: Tuah Talino Volume 12 Nomor 1

Himawan, RF. (2019). Penahbisan guyon saru dalam arena pertunjukan wayang kulit purwa di DKI Jakarta = The consecration of guyon saru in the field of Javanese shadow puppet theater in Jakarta. University Indonesia Library.

Kusumah, Adi Mega (2016). Persepktif Citra Wanita Dalam Kumpulan Lirik Lagu Dangdut Modern Periode Tahun 2015. UPI: Repository perpustakaan

Lahdji, Rima Firdaus (2015).Objektifikasi perempuan dan tubuh: wacana tubuh perempuan dalam lirik lagu dangdut populer tahun 2000-2013. Unair: FIB, Magister Kajian Sastra dan Ilmu Budaya.

Laili, Nurul (2015). Eksploitasi Wanita Dalam Media Hiburan (Analisis Framing Terhadap Lirik Lagu Dangdut "Mobil Bergoyang" dan "Wanita Lubang Buaya"). Jember: Digitalibrary IAIN Jember.

Lee, C.W. (2016). A study od Singapore’s English Channel Television Commercials and Sex-Role Stereotypes. Taylor \& Francis Online: Asian Journal of Women's Studies. 9(3).

Michael, O. (2019). Reading Phoebe Gloeckner's A Child's Life and Other Stories at the Time of \#MeToo. Life Writing 16(3), pp. 345-367.

Nicholas, J. (2015). The modern girl: Feminine modernities, the body, and commodities in the 1920s. The Modern Girl: Feminine Modernities, the Body, and Commodities in the 1920s, pp. 1-299.

Puji Sri Endra Kusumawati, Tri Marhaeni Pudji Astuti \& Sucihatiningsih Dian WP (2017). Biduanita Dangdut: Hegemoni \& Reaksi Atas Dominasi.

Saara Liinamaa \& Malia Rogers (2020): Women actors, insecure work, and everyday sexism in the Canadian screen industry, Feminist Media Studies, DOI: 10.1080/14680777.2020.1759114 (https://doi.org/10.1080/14680777.2020.17 59114)

Sajadieh, S., Wolfe, H. (2019). Come hither to me: Performance of a seductive robot. Conference on Human Factors in Computing Systems - Proceedings 3313287.

Sandra Bader \& Richter, M.M. (2014). Dangdut Beyond the Sex: CreatingIntercorporeal Space through Nyawer Encounters in West Java. Indonesia. Ethnomusicology Forum 23(3) Creative Intersubjectivity in Performance: Perspektives From The Asia-Pasific. 
Schmidt, A.F., Kistemaker, L.M. (2015). The sexualized-body-inversion hypothesis revisited: Valid indicator of sexual objectification or methodological artifact. Cognition 134, pp. 77-84.

Smolak, L., Murnen, S.K., Myers, T.A. (2014). Sexualizing the self: What college women and men think about and do to be "sexy". Psychology of Women Quarterly 38(3), pp. 379-397.

Stewart, A. (2016). Quiet beauty: problems of agency and appearance in evangelical Christianity. Religion 46(1), pp. 32-52.

Van Blommestein, S. (2013). The dancing whore and the body as spectacle: Ballet girls, gender construction, and the romance between ballet and prostitution. International Journal of Civic Political, and Community Studies 10(4), pp. 107-119.

Weintraub, A.N. (2010) Nation, Islam, and gender in dangdut, Indonesia's most popular music. University of Pittsburgh, United States Routledge Handbook of Contemporary Indonesia pp. 369-377.

Weintraub, A.N. (2018). Dangdut Stories: A Social and Musical History of Indonesia's Most Popular Music. University of Pittsburgh, United States. Dangdut Stories: A Social and Musical History of Indonesia's Most Popular Music. pp. 1-272.

Willoughby, H.A (2015). Under the cover: image and imagination in korean popular music albums. Taylor \& Francis Online: Asian Journal of Women's Studies 
